\title{
ArcheoSciences
}

Revue d'archéométrie

33 (suppl.) | 2009

Mémoire du sol, espace des hommes

\section{The contribution of archaeology to knowledge about the landscape}

Gertrudes Branco and Leonor Rocha

\section{(2) OpenEdition}

1 Journals

Electronic version

URL: https://journals.openedition.org/archeosciences/1532

DOI: 10.4000/archeosciences. 1532

ISBN: 978-2-7535-1599-4

ISSN: 2104-3728

Publisher

Presses universitaires de Rennes

Printed version

Date of publication: 30 October 2009

Number of pages: $173-174$

ISBN: 978-2-7535-0943-6

ISSN: $1960-1360$

Electronic reference

Gertrudes Branco and Leonor Rocha, "The contribution of archaeology to knowledge about the

landscape", ArcheoSciences [Online], 33 (suppl.) | 2009, Online since 30 October 2011, connection on

01 February 2022. URL: http://journals.openedition.org/archeosciences/1532 ; DOI: https://doi.org/

10.4000/archeosciences.1532 


\title{
The contribution of archaeology to knowledge about the landscape
}

\author{
Gertrudes Branco* and Leonor Rocha ${ }^{* *}$
}

Key word: Landscape, Archaeology, Prospection, Territory, Geographic Information Systems (GIS).

According to the definition formulated by Orlando Ribeiro (1986), the landscape is a product of the past; it is the result of forms of land use which have moulded the present-day natural environment, and may or may not contain material evidence of the past.

The landscape is thus conceptualised as a historical phenomenon, the result of human action on the natural environment which has impacts on nature, in terms of the introduction, maintenance and destruction and certain plant species, and creates new specific artificial features, like monuments, routes and structures.

There is a constant dialogue between the landscape as a dynamic space and human action, and underlying this relationship are the following assumptions:

a. the choice of sites for human settlement was strongly influenced by the natural features of the space;

b. the natural factors which affected this choice can be detected by the analysis of present-day environmental features;

c. the landscape contains information which is essential for an understanding of the societies which built it;

d. this knowledge can be accessed through the study of the dispersal and configuration of archaeological remains in the landscape;

e. material archaeological remains occupy the concrete space or the landscape and have a significant relationship with it which allows for an improved understanding of sites and the present-day landscape.

* Universidade de Évora, gertrudes.(branco@gmail.com)

** CIDEHUS/ Universidade de Évora. (Improcha@gmail.com)
The archaeology of the landscape constitutes a line of research whose objective is "to study archaeological remains in accordance with the spatial coordinates in which human action has taken place" (González Méndez, 1998/00: 57), a basic premise for the management and study of the archaeological record.

This working strategy enables an understanding of the spatial dimension of the archaeological record, enabling the improved management and study of archaeological resources. The mutual determinism of archaeological data and

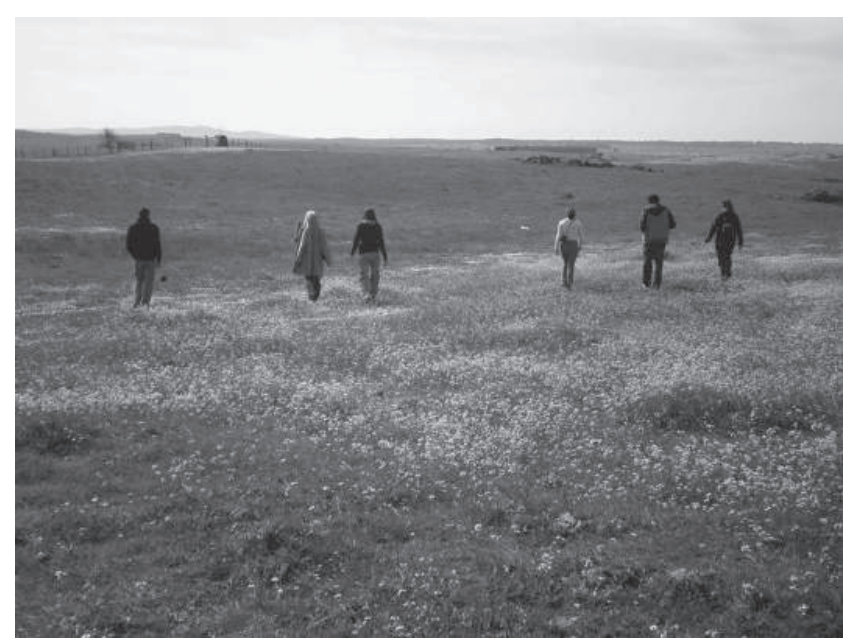

Figure 1: Field prospection. 
geographical data should be taken into account as part of research projects for territorial planning.

The success of such projects for the study, understanding and enhancement of the archaeological heritage depends crucially on the quality and quantity of the information available. In this field, archaeological prospecting work is a non-intrusive method which enables archaeological data to be obtained. By archaeological prospecting work we mean the direct visual survey of the land surface with the aim of identifying and recording material remains and/or structures related to past human activity.

The use of Geographic Information Systems (GIS) facilitates planning carried out prior to the execution of archaeological prospecting work and the processing and management of the data obtained. Such tools allow users to create interactive queries, analyse spatial information (by layer, examining archaeological sites and geographic features), edit data and maps, and present the results of all these operations.

As research tools, GIS develop new sources of potential for the analysis of the human influence on the landscape. When used in archaeological prospecting work, there is a range of new sources of potential which are relevant for scientific research and territorial planning:

1. for archaeological prospecting work at a preliminary stage:

1.1 the cartographic representation of areas covered by the project;

1.2 the signalling of toponymic features which are relevant for research;

1.3 the delimitation of areas with archaeological potential on the basis of geo-archaeological patterns established for the areas being studied;

1.4 the localization of identified archaeological sites during the course of previous studies in the field.

2. for archaeological prospecting work at a later stage:

2.1 the localisation and analysis of sites (as areas for the dispersal of materials) considering a range of cartographic variables, such as topography, land use, and lithology;

2.2 the cartographic representation of visible land features;

2.3 the cartographic representation of areas which have been the object of archaeological prospecting work, identifying areas with no archaeological potential;

2.4 the establishment of settlement patterns on the basis of type, chronology of identified sites and the physiographic unit of which they form part, defining different types of landscape: domestic landscapes, fortified landscapes, landscapes with art, and landscapes with monuments.

It should be stressed that the goal of the archaeology of the landscape is not to reconstruct the morphology of ancient landscapes, which a lack of data makes extremely difficult, but to obtain information which can provide increased knowledge about the societies of the past.

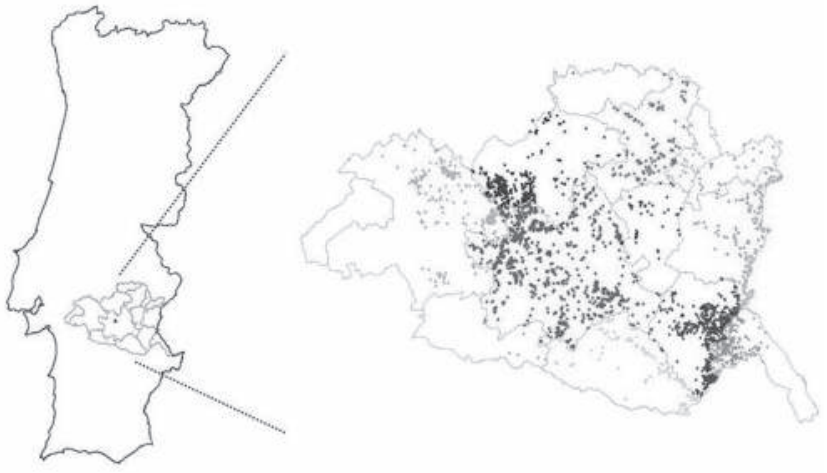

Figure 2: Cartographic representation (SIG) of archaeological places in Central Alentejo (Portugal).

\section{References}

Alaix, M. M. and Werner, J. P., 2001. Patrimonio y território: una reflexión sobre los proyectos de puesta en valor del patrimonio. Estudos.Património, 1: 38-41.

Criado Boado, F., 1996. La Arqueología del Paisaje como programa de gestión integral del Patrimonio Arqueológico. Boletín del Instituto Andaluz del Património Histórico, 14: 15-19.

Criado Boado, F., 1998. Proyecto Bocelo-Furelos: arqueologia del paisaje y prospeccion intensiva en Galicia. Trabalhos de Antropología e Etnologia, 28: 241-248.

EbERT, J. I., 2000. The state of the art in "inductive" predictive modeling: seven big mistakes (and lots of smaller ones). In Wesrcott, K. L., Brandon, R. J., (dir.). Practical Applications of GIS for Archaeologists. A Predictive Modeling Kit. Taylor \& Francis, London, 129-134.

GonZÁlez MénDEZ, M., 1998/00. Arqueología y desarrollo local: la arqueología del paisaje como recurso para el desarrollo integral de áreas rurales. Cadernos de Arqueología e Património, 7/8: 53-63.

González Méndez, M., 1999. Investigación y puesta en valor del Patrimonio Histórico. Planteamientos y propuestas desde la Arqueología del Paisaje. Universidade de Santiago de Compostela (publicacão en CD), Santiago de Compostela.

González Méndez, M., 2000. Memoria, historia y patrimonio: hacia una concepción social del patrimonio. Trabajos de Prehistoria, 57 (2): 9-20.

Lemos, F. S. and Roriz, A., 2003. Ordenamento do território e arqueologia. Almadan, II Série, 12: 109-114.

Llavori, R., 1998. Arqueologia y Planificación Territorial. Um procedimiento aplicado a la arqueología medioambiental. Complutum, 9: 311-334.

RiBeiro, O., 1986. Portugal o Mediterrâneo e o Atlântico. Sá da Costa, Lisboa.

Ruiz Zapatero, G., 2004. La prospección arqueológica de superficie en los inicios del siglo XXI. Arqueología Espacial, 24-25: 17-31. 